\title{
Mobilność zagraniczna polskich doktorów - możliwości i bariery
}

STRESZCZENIE. Artykuł przedstawia wyniki badań jakościowych dotyczących osób ze stopniem doktora, pracujących na polskich uczelniach, odnoszące się do ich mobilności międzynarodowej. Pod uwagę wzięto opinie o mobilności, doświadczenia mobilności (nieliczne staże naukowe wśród badanych), a także bariery, które według rozmówców utrudniają im mobilność. Szczególną uwagę poświęcono kwestiom rodzinnym (partnerom i dzieciom), a także kompetencjom językowym i warunkom pracy. Deklaracje dotyczące mobilności porównano z danymi na temat sposobów utrzymania się doktorów. Dla części doktorów dochód małżonka jest podstawowym źródłem utrzymania, z czego można wysnuć wniosek, że nie zaryzykują utraty przez małżonka pracy, nawet jeśli mobilność będzie bardziej wymagana niż obecnie.

SŁOWA KLUCZOWE: mobilność akademicka, gender, doktorzy, migracje

\section{Wprowadzenie}

Mobilność transnarodowa to dziś jedna z ważnych części składowych pracy naukowców, a w wielu miejscach świata także nieoficjalne lub oficjalne wymaganie zawodowe (Fahey i Kenway 2010a). Jej znaczenie uwidacznia się szczególnie w obliczu narastającej prekaryzacji zawodu naukowców i coraz mniejszych szans na znalezienie stabilnego zatrudnienia w pracy badawczej (Bauder 2015; Kwiek i Antonowicz 2015; Morano-Foadi 2005; Kim 2010) lub poza nią (jak w przypadku „postdoków” podejmowanych z braku innych możliwości pracy; Corley i Sabharwal 2007). Dla jednych mobilność jest pewnym etapem w życiu, dla innych - jego rutynową częścią (Fahey i Kenway 2010a). Liczba naukowców przemieszczających się globalnie rośnie znacząco, a uniwersytety stają się coraz bardziej transnarodowe (Fahey 
i Kenway 2010b)․․ Niektórzy autorzy (Altbach i Knight 2007; Kim 2010; Paradeise i Thoenig 2013) wskazują też na to, że zwiększanie transnarodowej mobilności akademickiej związane jest $\mathrm{z}$ coraz większym upowszechnieniem korporacyjnych standardów i praktyk w dziedzinie badań i produkcji wiedzy, tj. z koniecznością rywalizowania o zewnętrzne finansowanie badań, umiędzynarodowieniem naboru pracowników i studentów oraz zatrudnianiem na krótkie kontrakty. W krajach i na uczelniach stanowiących światowe centra produkcji wiedzy zagraniczni naukowcy są w tej korporacyjnej logice uważani za tanich i wydajnych, a szkolnictwo wyższe staje się usługą eksportową i przemysłem (Kim 2010: 580). Naukowcy afiliowani w centrach niechętnie wyjeżdżają na peryferie (Dillon 2001), chyba że wysokie płace i stanowiska rekompensują im straty (Lehn 2016). Z kolei na globalnych peryferiach świata naukowego, uzyskanie stopnia doktora lub staż podoktorski na prestiżowej uczelni sprzyja zatrudnieniu (Baruffaldi i Landoni 2012; Czaika i Toma 2015). Jednak w sytuacji gdy na krajowym rynku pracy trudno dostać akademicką posadę, prestiż instytucji goszczącej przestaje wystarczać jako zachęta do wyjazdu, a liczy się bycie na miejscu - wówczas naukowcy niechętnie wyjeżdżają na zagraniczne staże, co potwierdzają przypadki Korei Południowej (Kim 2010) i Japonii (Arai 2010). Z kolei szanse na dalsze zatrudnienie w instytucji, w której odbywa się staż zagraniczny, są niewielkie - pracodawcy przyjmujący mobilnych naukowców nie są zainteresowani dalszą karierą goszczonego „postdoka” ani jego pozostaniem w kraju tymczasowej rezydencji. Raczej cieszą się z dość taniej siły roboczej, która ciężko pracuje na rzecz całego zespołu (Musselin 2004: 68-69). W Europie, szczególnie w ramach Europejskiego Obszaru Szkolnictwa Wyższego i Europejskiej Przestrzeni Badawczej, mobilność jest również promowana jako sposób transferu wiedzy i umiejętności, rozwoju nauki, a także środek zapewniający Unii Europejskiej konkurencyjność wobec innych krajów (Kim 2010; Fahey i Kenway 2010a). Ale poza wszystkimi dobrodziejstwami mobilności, zwłaszcza związanymi z translokalnym uczeniem się (Zielińska 2016), naukowcy doświadczają także związanych z nią problemów. Jednym z najlepiej zbadanych jest problem ze znalezieniem zatrudnienia dla życiowego partnera (Vohlídalová 2014; Wagner 2011). Małżonkowie, szczególnie kobiety, często stają się „osobami towarzyszącymi” (Wagner 2011), czyli tied

${ }^{1} \mathrm{O}$ ile łatwo ustalić, ile osób przyjeżdża z zagranicy na studia doktoranckie, np. z Chin do Unii Europejskiej w 2007 r. przybyło ok. 6,5 tys. osób, podczas gdy z Meksyku do Stanów Zjednoczonych ok. 4 tys. osób (Boring, Flanagan, Gagliardi, Kaloudis i Karakasidou 2015), o tyle trudno ustalić skalę przemieszczania się doświadczonych naukowców, głównie ze względu na to, że jest to praktyka na ogół oddolna, a ponadto: a) mobilność geograficzna może, ale nie musi, wiązać się ze zmianą pracodawcy; b) wizyty różnią się długością i stopniem formalizacji; c) wyjazdy w to samo miejsce bywają powtarzane; d) nie zawsze dochodzi do powrotu. Z powodu jakościowego zróżnicowania mobilności bada się więc m.in. CV naukowców (Cañibano i Bozeman 2009) lub przepytuje ich w sondażach w badaniu przeprowadzonym w 2009 r. i obejmującym ponad 4,5 tys. naukowców w Unii Europejskiej ponad 60\% zadeklarowało, że ma doświadczenie składające się z co najmniej trzech miesięcy pracy w innym ośrodku (Boring i in. 2015). 
movers, a więc przemieszczają się bez zapewnionej posady w nowym kraju. Poświęcają wtedy swoją karierę dla kariery małżonka. Mężczyźni przemieszczają się dużo rzadziej za swoimi partnerkami, a naukowczynie w stałych związkach często rezygnują z wyjazdu bądź wyjeżdżają bez partnera, nawet jeśli z dziećmi. Czasem z powodu migracji związki się rozpadają (Vohlídalová 2014). Dużo mniej wiadomo o tym, jaka jest sytuacja dzieci podróżujących razem z rodzicami lub urodzonych podczas wyjazdu, choć Izabela Wagner (2011) wskazuje, że polscy naukowcy zmieniający kraj pobytu uważają zwykle migrację za dobrą dla swoich dzieci, umożliwiającą im nauczenie się innego języka i poznanie innej kultury.

Z badań ilościowych dotyczących mobilności osób ze stopniem doktora, pochodzących z Polski wynika, że jest ona niska - zarówno jeśli chodzi o mobilność krajową, jak i międzynarodową (Batorski, Bojanowski i Czerniawska 2009). Migracjom naukowców z Polski nie sprzyja koncentracja na dydaktyce, wyższe stopnie naukowe, wiek i płeć żeńska (Batorski, Bojanowski i Czerniawska 2009: 5-6). Choć wyniki badań nad naukowcami z całej Unii Europejskiej wskazują, że migrują głównie mężczyźni, to mobilnych naukowców w Europie jest procentowo więcej niż w Polsce - to ponad połowa wszystkich zatrudnionych w sektorze edukacji wyższej (IDEA Consult 2010: 130). Dlaczego mobilność polskich naukowców utrzymuje się na tak niskim poziomie? W artykule przyjrzymy się wypowiedziom osób ze stopniem doktora zatrudnionych na polskich uczelniach, których odpowiedzi zbadano w ramach inicjatywy Nowe Otwarcie Uniwersytetu (NOU) (Kowzan, Zielińska, Kleina-Gwizdała i Prusinowska 2016). Weźmiemy tu pod uwagę wypowiedzi rozmówców na temat mobilności, szczególnie mobilności zagranicznej, gdyż była ona jednym z tematów prowadzonych w ramach NOU wywiadów ${ }^{2}$.

\section{Raport Nowego Otwarcia Uniwersytetu}

Raport Nowego Otwarcia Uniwersytetu (NOU), wydany na początku 2016 r., opiera się na badaniach prowadzonych wolontaryjnie przez grupy naukowców z Gdańska, Bydgoszczy i Warszawy w latach 2012-2013 na różnych uczelniach (Politechnice Gdańskiej, Uniwersytecie Gdańskim, Uniwersytecie Kazimierza Wielkiego, Uniwersytecie Technologiczno-Przyrodniczym im. Jana i Jędrzeja Śniadeckich w Bydgoszczy oraz Uniwersytecie Warszawskim). Celem badania było zdobycie wiedzy na temat postrzegania swojej sytuacji społeczno-ekonomicznej przez środowisko akademickie oraz warunków pracy i studiowania na uczelniach w Polsce. Wywiady przeprowadzano ze studentami, doktorantami i pracownikami naukowymi (ze stopniem doktora oraz z samodzielnymi pracownikami naukowymi). Podstawą raportu i poniższego materiału jest 30 wywiadów z doktorami, wśród których byli

${ }^{2} \mathrm{~W}$ artykule wykorzystujemy fragmenty raportu naszego autorstwa. 
przedstawiciele takich dyscyplin naukowych, jak: biologia, biotechnologia, chemia, ekonomia, filologia polska i inne filologie, fizyka, historia, kulturoznawstwo, mechanika, oceanografia, pedagogika, psychologia, socjologia i telekomunikacja; w wieku 32-62 lata. Prowadzono wywiady narracyjne, biograficzne, z dyspozycjami, które następnie analizowano, wyodrębniając kategorie - zarówno pochodzące z samych wywiadów, jak i ze scenariusza wywiadu. Najważniejsze wątki przedstawiono w 176-stronicowym raporcie, który dostępny jest w formie elektronicznej (Kowzan i in. 2016). Część rekonstrukcyjną podzieliliśmy na sekcje dotyczące historii zmian znaczenia mobilności, oceny korzyści płynących z mobilności oraz barier w mobilności, ze szczególnym uwzględnieniem roli partnerów życiowych, dzieci, płacy i znajomości języków obcych. Artykuł kończy się podsumowaniem zawierającym wnioski dla polityki publicznej dotyczącej sektora nauki i szkolnictwa wyższego, mającej na celu zwiększanie mobilności polskich naukowców.

\section{Historia zmian}

W wypowiedziach respondentów znalazły się informacje o mobilności jako o stosunkowo nowym zjawisku, które pojawiło się na uczelniach. Takie zdanie wyrażane było szczególnie przez tych, którzy pracowali tam od dawna. Jeden z rozmówców wspominał o znaczącej zmianie - w kontekście pokoleniowym - w zakresie możliwości realizacji pracy naukowej czy nawiązania współpracy badawczej za granicą:

$Z$ mojego, że tak powiem, rocznika, czy tamtego okresu, to wygladaja [te historie] podobnie. Bo to nie tylko ja, ale nikt nie miat możliwości gdzieś tam pojechać na Zachód. To były jakieś tam możliwości dla wybranych naprawdę, gdzieś tam ktoś sobie sam prywatnie coś takiego zorganizowat. Nie byto jak gdyby żadnej takiej formy... instytucjonalnej, nie wiem, jakiejś takiej, że po prostu latwo to załatwić. Nie bylo programów takich, nie braliśmy udziału, nie byliśmy $w$ Unii Europejskiej. No to zupetnie inne czasy byly. Natomiast jeżeli chodzi o młodszych pracowników, no to oczywiście już kilka lat później to się znacznie poprawiato, pootwierało. I oni, bym powiedział, rzeczywiście wyjeżdżali więcej na jakieś tam staże itd. Tak że to się na pewno zmienito pod tym względem zdecydowanie [M1, 40-50, uniwersytet, nauki przyrodnicze].

Co jednak ważne, ten sam rozmówca, który nie miał możliwości wyjazdu w czasach, gdy było to trudne, obecnie nie był już tym zainteresowany. Było to związane z rozwojem jego kariery - jak twierdzi, ze zdobyciem samodzielności w rozwoju:

Ja na żadnych stażach nie bytem. Bardzo niemobilny jestem naukowo, [...] w okresie jakimś tam pierwszym po studiach, rzeczywiście ja się staratem o różne staże, ale to były czasy takie, gdzie po prostu nie można było. [...] A później jak gdyby w sytuacji, $w$ której,jak gdyby osiaggnątem jużjakiś tam taki poziom, że bytem $w$ stanie się tutaj finansować i rozwijać samodzielnie, to już nie miatem ochoty. O tak bym to określit, że dzisiaj jest inaczej [M1, 40-50, nauki przyrodnicze]. 
Jak widać, mobilności nie sprzyjają pierwsze niepowodzenia, ale też upływ czasu - wraz z nim bowiem ludzie jakoś układają sobie życie i pracę, a zmiana tego rytmu byłaby trudna, wymagałaby dezorganizacji całej codzienności i swojej, i rodziny.

Wydawałoby się jednak, że rozbudowana infrastruktura wspierająca akademicką mobilność w Europejskiej Przestrzeni Badawczej oraz lepsze perspektywy kariery osób mobilnych (Bauder 2015) powinny zachęcać młodych pracowników naukowych do wyjazdów, szczególnie z kraju, w którym dominują feudalne stosunki władzy na uczelniach (Kwiek i Antonowicz 2015) i chętnych powinno być wielu. A jednak niektórzy twierdzą, że to właśnie feudalne stosunki władzy zniechęcają do wyjazdów naukowców, którzy chcieliby pozostać „,w grze” o akademickie stanowiska pracy (Jarausch 2005; Morano-Foadi 2005; Bauder 2015). Nasi rozmówcy wskazywali natomiast na wiele innych przyczyn podjęcia decyzji o wyjeździe bądź rezygnacji z mobilności.

\section{Ocena korzyści płynących z mobilności}

Uczestnicy badań wysoko oceniali mobilność i jej rolę w życiu naukowca - badani przez nas doktorzy widzieli, że przyczyniła się ona lub mogła przyczynić do rozwoju kariery naukowej i współpracy między różnymi ośrodkami. Jeden z rozmówców wskazywał na rolę takiego wyjazdu w rozumieniu świata i swojej dziedziny nauki:

Trzeba jednak iść tym tropem Skandynawów, że trzy języki obce się zna, czyli jeden niszowy. Typu właśnie polski czy węgierski. Dobrze by było, żeby na to postawić, bo to teżz drugiej strony by wymusito większą mobilność,jak myjedziemy gdzieś, to od razu się robi zainteresowanie, to może trzeba przyjechać tu do nas. I to jakby wymuszało też na kadrze przygotowywanie się, przynajmniej w obcym języku, poznanie jeszcze jednego, poza angielskim języka i komunikowanie się, to dynamizuje znacznie. Ja to widzę po sobie. Od czasu, kiedy zacząłem mieć kontakty z Europa, zupetnie inaczej [patrzę] na wiele rzeczy. Wiele bajek, które koledzy starsi opowiadali, czyli że tojuż sa bajki, a nie, że tak świat wygląda. No, ale podróże ksztatca [M2, 50-60, humanistyka].

Doktorzy mówili także o tym, jak staże i wyjazdy łączą się z podejmowaniem współpracy z innymi ośrodkami akademickimi, co ostatecznie, w wielu wypadkach, prowadziło do wspólnych publikacji:

Tak, no, jako zaklad wspótpracujemy, no profesor bardzo się stara w ogóle o to, żeby ta wspótpraca z różnymi ośrodkami była i mamy bardzo dobra wspótpracę [w różnych krajach - M.Z. i P.K.] [...] doktorantki wyjeżdżają do [odległego kraju] na..., to jest taki staż $w$ ramach doktoratu, który one musza odbyć, więc mamy z bardzo różnymi ośrodkami, też piszemy wspólne publikacje, jak najbardziej, tak i to, że razem wspótpracujemy i mamy szerokie kontakty z również znaczącymi placówkami 
$w$ tej dziedzinie [...]. To później procentuje w różnych staraniach, że jest wspólpraca z bardzo dobrymi placówkami, razem publikujemy [K1, 30-40, nauki przyrodnicze].

W przypadku respondentów reprezentujących nauki ścisłe takie kontakty umożliwiały także korzystanie z niedostępnego sprzętu czy wykonywanie bardziej skomplikowanych analiz:

Każdy ma $w$ zespole założony udziat, przynajmniej raz $w$ roku, $w$ poważnej konferencji międzynarodowej, bo my rozróżniamy takie konferencje międzynarodowe, które sq tu $w$ Polsce prowadzone i one mają mało wspólnego z konferencjami międzynarodowymi. [...] one niewiele po prostu wnosza do rozwoju naukowego, natomiast udziat $w$ kongresach swiatowych, $w$ konferencjach światowych tacznie... $w$ połaczeniu z wystapieniami publicznymi pozytywnie wplywa na promocję naszych wyników, naszej jednostki i są tego żywe przykłady co roku. Praktycznie po każdej konferencji i kongresie na świecie wracamy z plikiem materiatów, które są nie do zebrania nigdzie indziej, bo to sq niepublikowane zbiory abstraktów, z których korzystamy później $w$ badaniach, z kontaktami, z naukowcami, tymi naprawdę..., no doskonatymi, z ekspertami, którzy sq wiodący $w$ dziedzinach, które nas interesuja, a poza tym z możliwościami nowej wspótpracy. I tak się stało nawet [...] po ostatniej konferencji, w której ja bratam udziat. [...] to są wtaśnie efekty takich wyjazdów, nawiazywania wspólpracy, przelamywania siebie i wykorzystywania tego, że ludzie tam, ci, co organizuja takie wydarzenia, sq naprawde otwartymi ludźmi i no, po prostu z ta świadomościq można iść do przodu. Dlatego jak najbardziej mobilność tak, realizacja stażów zagranicznych też. Realizacja badań w innych laboratoriach też, ponieważ wielokrotnie mieliśmy okazję dzięki temu korzystać ze sprzętu, który $w$ naszym przypadku jest niedostępny na miejscu, więc faktycznie tutaj sama mobilność oznacza też możliwość w ogóle zrealizowania badań bardziej zaawansowanych technicznie, analiz wykonanie [K2, 30-40, nauki techniczne].

Taka wymiana, współpraca i umiędzynarodowienie pracy akademickiej osiągane były m.in. dzięki składaniu aplikacji na finansowanie projektów międzynarodowych:

My akurat mamy bardzo taką dobrą wspótpracę z wieloma ośrodkami [...]. Dziewczyny jeżdżą do [Europy Północnej - M.Z. i P.K.], [...] ja byłam $w$ [dwóch innych krajach], po prostu, więc jeśli chodzi o pracę, to wymiana jest. Przyjeżdżają też do nas, rzadko, ale przyjeżdżaja, studenci z zagranicy, właśnie teraz mamy, w czwartek przyjedzie doktorantka z Hiszpanii, była już tutaj w październiku, teraz dalej będzie tutaj robita badania. Więc jakby ta nasza pracownia, pani profesor należy do takich osób, które lubia jeździć na spotkania międzynarodowe, ma kontakty z tymi osobami $i$ stąd te wymiany. [...] mi się wydaje, że to $w$ takim kierunku zmierza, że jednak będzie ta wymiana. Dużo projektów też jest na to składanych, więc na to sq czasami takie projekty, które stuża tylko wymianie międzynarodowej, jest na uczelni dużo i my też $w$ takich uczestniczymy [K3, 30-40, nauki przyrodnicze]. 
Z przytoczonych fragmentów wynika, że o jakość współpracy międzynarodowej dbali przede wszystkim bezpośredni przełożeni naszych rozmówców. Przy tym gwarancją odpowiedniej częstotliwości wyjazdów było przypisywanie ich do określonego etapu rozwoju kariery (,taki staż w ramach doktoratu, który one muszą odbyć”), okresu rozliczeniowego („każdy ma w zespole założony udział, przynajmniej raz w roku, w poważnej konferencji międzynarodowej”) lub poświęconych tylko temu celowi projektów („na to są czasami takie projekty, które służą tylko wymianie międzynarodowej”).

Mobilność była też postrzegana jako ważna przez tych, którzy się na nią wcześniej zdecydowali. Dawała ona porównanie i umożliwiała lepszą ocenę swoich obecnych warunków pracy. Czasem rezultatem było niezadowolenie z obecnej sytuacji:

I $w$ tych wszystkich miejscach, $w$ których byłam zagranica, to zawsze bardzo fajnie funkcjonowato. Że [...] jednak codziennie przyjeżdżałam do instytutu czy na wydział. Miałam swoje biurko, swój komputer, swoje papiery i mogłam sobie tam siedzieć i coś robić. I potem zamykałam, posztam do domu czy coś takiego. Natomiast tutaj jest [to] absolutnie niemożliwe do wykonania, z powodów [...] technicznych [K4, 3040, nauki społeczne].

Tymi powodami były złe warunki lokalowe, co szerzej analizujemy w innym miejscu samego raportu (Kowzan i in. 2016: 37-40 142-143)3.

Osoby, które wyjeżdżały wcześniej, w czasie studiów czy pisania doktoratu, opowiadały też o swoich planach wyjazdowych i o wnioskach stypendialnych, które składały w późniejszym czasie. Jedna z respondentek twierdziła, że żałuje, iż na wyjazdy zdecydowała się tak późno:

B: Czy jak patrzysz dzisiaj na swoją karierę naukowa, czy widziałabyś, gdybyś miata możliwość rozpoczęcia jeszcze raz, czy wybrałabyś taka samą drogę, czy coś byś zmodyfikowata?

R: Zmodyfikowałabym o tyle, że wcześniej bym się zabrała za wyjeżdżanie na różne zagraniczne stypendia. Albo być może bym pojechała na jakiś doktorat gdzieś indziej $w$ świat. [...] bym się wcześniej zabrała za jakieś Fullbrighty i za jakieś może na jakiegoś postdoca mogłam się postarać. [...] No bo teraz to jest trudniej, mam cała ekipe zebrać i gdzieś tam z nimi pojechać. [...] i tak chcę pojechać, no ale właśnie to jest trudniejsze logistycznie. Mi jest trochę ciasno w Polsce. Myślę, że trzeba właśnie dużo jeździć $i$ się dowiadywać, jak to wygląda gdzieś indziej [K5, 30-40, nauki społeczne].

Rozmówczyni była entuzjastycznie nastawiona wobec samych wyjazdów, widziała jednak problemy organizacyjne związane z przemieszczaniem się z rodziną

${ }^{3}$ Braki sprzętowe oraz ciasnota przekładały się na niechęć do miejsca pracy, marnowanie czasu na znalezienie miejsca dla siebie, szczególnie w czasie egzaminów, oraz wykonywanie swoich obowiązków poza miejscem pracy. 
(„całą ekipę zebrać”), i - jak zobaczymy dalej - nie była to opinia odosobniona. Również jako trudny ze względu na rodzinę oceniła swój wyjazd inna rozmówczyni:

Ja już byłam $w$ [kraju na południu Europy], mam kontakt z osobami, które tam pracują, nadal utrzymuję takie kontakty, ale chyba już bym nie chciała tam jechać drugi raz, teraz, przynajmniej na tym etapie życia, bo odbyłam, te póltora roku odbyło się kosztem mojej rodziny i mojego życia prywatnego, bardzo się odbiło [...] mam to już za soba, taki staż zagraniczny jest bardzo potrzebny $w$ karierze, chociaż teraz nie jest już wymagany $w$ przypadku habilitacji, kiedyś byt, był obowiązkowy, to mimo wszystko powrót z niego i to prestiżowe stypendium, które otrzymałam, zaprocentowało później innymi, może nie tyle ciekawymi propozycjami, co różnym udziałem $w$ różnych projektach [K1, 30-40, nauki przyrodnicze].

W tej wypowiedzi korzyści dla kariery naukowca zestawione są z kosztami ponoszonymi w obszarze życia rodzinnego. Ten wątek nie został rozwinięty, ale inne badania wskazują np. na częsty rozpad związku ze względu na wyjazd (Vohlídalová 2014).

Choć opinie o mobilności i współpracy międzynarodowej były bardzo pozytywne, to tylko znikoma liczba naszych rozmówców miała w swoim doświadczeniu staże zagraniczne czy dłuższe wyjazdy na wymianę międzynarodową. Przyjrzyjmy się więc możliwym przyczynom takiej sytuacji.

\section{Bariery w mobilności}

Wśród barier w międzynarodowej mobilności wymieniano przede wszystkim bariery „organizacyjne”, związane szczególnie z ułożeniem sobie życia za granicą, jeśli chodzi o partnera, dzieci czy pracę. W dalszej części przenalizujemy kolejne przeszkody, omawiając kwestię partnera i dzieci badacza, języka oraz warunków pracy i płacy w Polsce.

\subsection{Partnerzy}

Małżeństwo jest jednym z poważniejszych czynników ograniczających mobilność pracowników akademickich z stopniem doktora, szczególnie dotyczy to kobiet w nauce. Choć wśród „singli” prawdopodobieństwo mobilności akademickiej jest zbliżone u kobiet i mężczyzn, to już wśród osób będących po ślubie znacznie rzadziej migrują kobiety (Vohlídalová 2014: 90). Małżeństwo, poprzez ograniczenie mobilności, może również niekorzystnie wpływać na zarobki naukowców (Kidd i Green 2006). Jeden z rozmówców mówił o swoim braku mobilności w następujący sposób: 
No w dzisiejszych czasach to takjest, że rodziny praktycznie nie ma szans się zabrać, bo jeżeli ja na rok mam wyjechać i wziąć swoje dzieci i przerwać im na przyktad naukę $w$ szkołach, przedszkolach, zerwać pracę żony i wrócić za rok. [...] to nie ma dla mnie sensu. Bo moja żona musiatby zerwać pracę, a ja nie zarabiam tyle na uczelni, żebym bytją $w$ stanie byt utrzymać i podobnie jest z innymi rzeczami. [...] Jeżeli bym jechat z rodzina. No bo moge jechać bez, oczywiście, ale wtedy to tak jest bardziej delegacyjnie załóżmy [M3, 30-40, nauki techniczne].

Wypowiedź ta wskazuje na wagę związków rodzinnych w decyzjach migracyjnych, co dla wielu osób jest istotnym czynnikiem utrudniającym wyjazd. Badania Izabeli Wagner przeprowadzone wśród polskich naukowców posiadających doświadczenie pracy za granicą pokazują, że przeszkoda ta dotyczy głównie kobiet do wyjątków należą te, które decydują się na mobilność, mając już rodzinę, podczas gdy u mężczyzn problem ten nie jest aż tak istotny (Wagner 2011: 129). Co ciekawe, rozmówca nie martwił się bardzo samą karierą żony, ale raczej kwestiami finansowymi, uniemożliwiającymi mu utrzymanie rodziny z jednej pensji, choć jak wskazują badacze (Ackers 2004; Vohlídalová 2014; Lehn 2016: 170-171, 208-210), to właśnie kariera małżonka cierpi najbardziej.

By jednak uzyskać lepszy wgląd w kwestię pracy małżonków, warto odwołać się do innego fragmentu raportu NOU, w którym analizujemy dochody doktorów ${ }^{4}$. Jednym z najczęstszych sposobów radzenia sobie z niskimi zarobkami oferowanymi przez polskie uczelnie publiczne było poleganie na zarobkach małżonka przede wszystkim mężczyzny. Nauka była w tym kontekście postrzegana często jako hobby czy wręcz zajęcie filantropijne dla żon bogatych mężów, na co wskazuje kilka poniższych cytatów:

Całe szczęście mam męża, więc nie jest źle. [...] Myślę, że jakość mojego życia jest całkiem nie najgorsza [śmiech], no ale myślę, że to jest też zasługa tego, że mój mąż pracuje [K6, 40-50, humanistyka].

My wiążemy koniec z końcem, ale to jest sytuacja, w której mój mą̇̇ zarabia znacznie lepiej niż ja $w$ danej chwili. [...] Ja jestem zadowolona, tylko podkreślę, że gdybym była samotna matka, to bym była niezadowolona z tej pensji. Gdybym była myślę, że sama, na przykład singielką, to myślę, że też bym nie była zadowolona. Mój komfort finansowy i mój komfort bytowy zapewnia podwójna pensja $w$ rodzinie [...] z duża dysproporcją na korzyść pensji mojego męża [K7, 30-40, humanistyka].

No ciężko by mi bylo znaleźć osobę, która zarabia mniej ode mnie spośród osób mi znanych [...]. Mój ojciec kiedyś się śmiat, dawno temu za komuny [...], że moja mama zarabia na przystowiowe papierosy, [...] że równie dobrze moja mama by mogła nie chodzić do pracy, ale chodzila do tej pracy, bo chciała. Ja też mam takie wrażenie, [...] że ja zarabiam na przystowiowe papierosy [...]. Gdyby mój maż nie zarabiał

${ }^{4} \mathrm{~W}$ tej części wykorzystujemy fragmenty raportu naszego autorstwa. 
tyle, ile zarabia, no to generalnie na pewno bym tu nie pracowała, także to jest takie trochę, powiedziałabym, jednak hobbystyczne... [K8, 30-40, humanistyka].

Na takie hobby mogły sobie jednak pozwolić przede wszystkim kobiety, część z nich wskazywała bowiem, że to mężczý́ni byli odpowiedzialni za utrzymanie rodziny. Zauważały to zarówno kobiety, jak i mężczyźni, odnosząc się zarówno do czasu pisania doktoratu, jak i dalszej pracy:

Kilkanaście osób poszto na doktorat, tylko niewiele z nich skończyto, ponieważ no nie mieli za co się utrzymać. [...] Głównie panowie odchodzili, bo jak mają rodziny, no to za tysiac złotych ze stypendium rodziny nie utrzymaja już. Stąd te kierunki przyrodnicze sq sfeminizowane, tam gdzie sq mate zarobki, bo to jednak ta rola spoteczna mężczyzn, mężczyzna ma bardziej zarobić na dom. To się może odwracać, ale mówię, taki jest stereotyp, a kobieta może się zajmować swoją pasją [K3, 30-40, nauki przyrodnicze].

Inny rozmówca zaś opowiadał:

Moim wszystkim dyplomantom, których miałem $w$ życiu możliwość promować, którzy sq moimi kolegami już często teraz, to $w$ życiu [bym tej pracy nie polecal]. Oni szli do firm, oni zarabiają więcej ode mnie i to jest najważniejsze. [...] To nie jest $w$ ogóle robota dla facetów. [śmiech] [...] mężczyzna ma być zawsze głowa rodziny, a wiadomo jest, że jeżeli na uczelni się dużo nie zmienia, to zarobki sq coraz niższe. [...] a praca na uczelni, o ile kiedyś, dwadzieścia lat temu, była gwarantem tego, że się do emerytury dotrwa, to teraz nie jest, bo [na] wszystko jest czas. Czyli osiem lat na doktorat, osiem na habilitację, osiem na to. Wszystko jest $w$ czasie. To lepiej być $w$ firmie, bo tam nie ma takiego czasu, po ośmiu latach jest jednak się wyżej [M3, 30-40, nauki techniczne].

Były jednak pewne wyjątki od tej reguły, np. sytuacja mężczyzny, który chciał poświęcić się pracy naukowej i żona brała dodatkowe zlecenia, żeby mogli się utrzymać. W końcu jednak po jej protestach, rozmówca wziął na siebie część ciężaru związanego z dodatkowymi zleceniami. Jakie są jednak konsekwencje takiej sytuacji, gdy nauka postrzegana jest jako hobby dla kobiet? Jedną z nich jest niedocenianie tej pracy, także przez małżonków:

Czas, który tutaj spędzam, to jest jedyny powód do kłótni czasami między nami, bo on [mąż] uważa, że za dużo pracuję za te pieniążki, które tutaj otrzymuję, że powinnam więcej czasu spędzać z dziećmi, w ogóle $w$ domu. Natomiast, no jak dochodzq takie dodatki i no widać sens tej pracy, to nawet on już mniej komentuje moje tutaj przesiadywania [K1, 30-40, nauki przyrodnicze].

Rola kobiety sprowadzona jest tu do zajmowania się dziećmi - poświęcenie czasu na coś innego może być uzasadnione odpowiednimi zarobkami (dodatki 
sprawiają, że praca nabiera sensu), bez nich jest stratą czasu. Sama rozmówczyni sprowadza swoją pracę do „przesiadywania”, co jest umniejszającym określeniem nadawanym tej pracy być może przez męża, podczas powracających kłótni na ten temat. Inną konsekwencją jest to, że jeśli praca (kobiety) na uczelni jest tylko niewielkim źródłem zarobków („,na papierosy”), to można z niej zrezygnować, gdy praca męża tego wymaga. Weźmy pod uwagę następującą wypowiedź:

Mój mąż stwierdzil, jako student, że on nie będzie tu za 2000 pracowat, bo nie utrzyma nas i w ogóle optaty i dzieci, przedszkole. To jako student wyjeżdżał sezonowo do Norwegii. No i niestety do pracy fizycznej, bo innej tam nie bylo. [...] jeżeli mąż by dostat jaką́s sensowna pracę $w$ Norwegii, to najprawdopodobniej ja nie wyobrażam sobie życia: tu my, on tam, takiego nie wiem, taty chwilowego, więc najprawdopodobniej przeprowadzilibyśmy się tam wszyscy. Ja bym wtedy tam szukała pracy, być może pisałabym też o jakieś stypendium bądź staż na jakiejś uczelni norweskiej [K1, 30-40, nauki przyrodnicze].

To praca mężczyzny musi - według prezentowanej tu logiki - utrzymać rodzinę, dlatego nie może on sobie pozwolić na pracę za pensję podobną do pensji adiunkta. Nawet fizyczna, sezonowa praca w Norwegii jest od tego lepsza, a praca naukowa żony jest na odległym miejscu, można z niej zrezygnować na rzecz lepszej pracy męża i przeprowadzki całej rodziny - choć kalkulacja ta zapewne uległaby zmianie na korzyść pracy naukowej, gdyby ta rozmówczyni znalazła pracę na uczelni w Norwegii. Tu dochodzimy więc do kwestii migracji ${ }^{5}$ - o ile w prezentowanej wcześniej logice trudno wyobrazić sobie, żeby dobrze zarabiający mąż zrobił przerwę w karierze na rzecz rozwoju nauki, czyli „hobby żony”, o tyle w grę wchodziła migracja wtedy, gdy migrował przede wszystkim mąż - choćby do pracy nieakademickiej. Nasi rozmówcy nie opowiadali o przypadkach migracji dwojga naukowców będących parą (dual career), ale jak wskazują inne badania, związki osób pracujących w tej samej branży nie sprzyjają mobilności (Ackers, Balch, Scott, Currie i Millard 2009). Taka mobilność jest wyjątkowo trudna ze względu na charakter ogłoszeń o pracę - niemal zawsze skierowanych do jednej osoby. Co więcej, osoby mające małżonka w tej samej lub podobnej branży opowiadały, że borykają się z poważnymi problemami finansowymi.

Przeszkoda związana z partnerem nie dotyczyła zresztą tylko osób mających dzieci czy dobrze zarabiających małżonków, ale także osób w związkach nieheteroseksualnych. Dla jednej z naszych rozmówczyń - w związku homoseksualnym -

${ }^{5}$ Migrację definiujemy tu za Stephenem McNairem (2009: 12) jako ruch „ludzi przemieszczających się pomiędzy terenami, aby tam mieszkać (a nie jedynie odwiedzać je)”, bez zakładania minimalnego czy maksymalnego czasu pobytu w danym miejscu. Jest ona więc w tym artykule tożsama z mobilnością, którą z kolei rozpatrujemy w kontekście właśnie przemieszczania się, aby gdzieś mieszkać i pracować, wyłączając z tego np. wyjazdy konferencyjne. 
sytuacja rodzinna, a właściwie oczekiwana reakcja pracowników administracyjnych na jej sytuację rodzinną również utrudniała mobilność międzynarodową:

B: Wspominataś w pewnym momencie, że zastanawiasz się nad tym, czy nie skorzystać z jakiegoś stypendium, czy nie wyjechać. Czy twoja sytuacja prywatna ma na to wptyw?

R: No tak, oczywiście, że to jest niemożliwe, ponieważ my jesteśmy po ślubie, to niemożliwym jest prawdopodobnie uzyskanie tutaj czy aplikowanie o taki staż, żebyśmy jechały razem. Natomiast jak polecimy do [kraju europejskiego], a tam już [imię] się orientowała, stąd też ten staż, o którym mówię, on jest całkiem prawdopodobny [...]. Być może będziemy aplikowały już za granica $w$ krajach, $w$ których rozpoznane sq nasze związki. Bo dzięki temu będziemy mogły lecieć tam razem i być razem, tak jak $w$ normalnym związku. Nie wyobrażam sobie, że tutaj będę komuś opowiadała, że mam żonę $i$ że właśnie chciałabym z żoną. To jest dla mnie coś niewyobrażalnego [K9, 30-40, nauki społeczne].

Co ciekawe, bycie w związku homoseksualnym utrudniało rozmówczyni wyjazd na staż zagraniczny, jeśli w procesie zgłaszania się o niego musiałaby informować uczelnię o swoim związku. Nie było to jednak przeszkodą w samodzielnym szukaniu miejsca na uczelni zagranicznej.

\subsection{Dzieci}

Podobnym, choć jednak częściowo odrębnym, problemem była organizacja życia własnych dzieci w przypadku wyjazdu zagranicznego. Jak pokazują badania przeprowadzone wśród naukowców z krajów Unii Europejskiej, spośród praktycznych barier dla mobilności naukowcy najczęściej wymieniają jakość i cenę mieszkania, opiekę nad dziećmi oraz system opieki społecznej, a dopiero w dalszej kolejności język czy integrację w nowym kraju (IDEA Consult 2010: 93). O opiekę nad dziećmi martwi się więcej kobiet niż mężczyzn i jest to ich największy problem spośród praktycznych (organizacyjnych) barier, jest ono też zdecydowanie częstsze u tych, którzy nie są mobilni, niż u tych, którzy na mobilność się zdecydowali. Jednocześnie np. kwestia mieszkania bardziej martwiła mobilnych niż niemobilnych naukowców (IDEA Consult 2010: 94). Także wśród czynników osobistych wpływających na mobilność najczęstszym (szczególnie dla kobiet) była troska o satysfakcję z życia u dzieci, dalej o równowagę między pracą a życiem rodzinnym, o utrzymanie swoich relacji osobistych z innymi i dopiero na czwartym miejscu o satysfakcję życiową i zawodową partnera (IDEA Consult 2010: 101). Taką troską o sytuację dziecka wykazała się np. jedna z rozmówczyń - samotna matka. Spytana, czy gdyby miała możliwość, wyjechałaby do pracy na uczelni zagranicznej, odpowiedziała: 
Gdybym dostała taka propozycję, to bym ją rozważała poważnie. Tylko że mam małe dziecko i to wiadomo, że też muszę myśleć o niej $w$ tym momencie, o organizacji życia jej - co z przedszkolem, a co ze szkoła, a co zjęzykiem itd., itd. [...], ale ja jakoja byłabym skłonna przyjąć tę propozycję [K10, 30-40, humanistyka].

Ciekawe jest tu rozróżnienie na „ja jako ja” i ,ja jako matka” - co sugeruje, że w zależności od przyjętej roli decyzja byłaby inna, choć przecież obie funkcje pełnione są jednocześnie. Inna, wcześniej już cytowana rozmówczyni, mówiła o problemach z zabieraniem „całej ekipy”, czyli dwójki dzieci i męża - choć w jej przypadku udało się pokonać ten problem i zdecydowała się na wyjazd. Jej dzieci były w wieku przedszkolnym. Tylko jeden rozmówca wspominał o dzieciach w wieku szkolnym (,jeżeli ja na rok mam wyjechać i wziąć swoje dzieci i przerwać im na przykład naukę w szkołach, przedszkolach, zerwać pracę żony i wrócić za rok. [...] to nie ma dla mnie sensu”). Nasze dane nie pozwalają stwierdzić, czy posiadanie dzieci w wieku szkolnym ograniczało mobilność bardziej (w przeprowadzonych przez nas wywiadach brakuje wypowiedzi na ten temat), jednak badania prowadzone wśród migrantów (Zielińska, Kowzan i Ragnarsdóttir 2014) wskazują, że często dają sobie oni czas na podjęcie decyzji o wyjazdach lub powrotach właśnie do momentu rozpoczęcia przez dziecko edukacji szkolnej. O innym problemie, związanym z mobilnością krajową, mówiła natomiast inna rozmówczyni:

Dobrze jest, jeśli ktoś pojedzie na stypendium. Natomiast nikt raczej nie jeździ. [...] Nie jest tak, że nikt. Jest [imię], który teraz pojechat do [nazwa kraju]. [...] I tak jak teraz na przykład mieliśmy przyjąć jakiegoś nowego pracownika, to on nie chciał się przenieść z [innego dużego miasta]. No bo to za daleko od jego miejsca zamieszkania. Ijest coś w tym akurat. To jest taki aspekt mobilności. Myśmy zaproponowali mu na pewno 2 tysiace złotych. A on by musiał tam zrezygnować ze swojej mamy, która jest opiekunka jego dzieci. Coś takiego przemknęło w tej rozmowie. Więc ja się zaczęłam $w$ pierwszym momencie, myślę sobie, no absurd. [...] Natomiast jak się zaczynam zastanawiać, no to ja też bym się nie zdecydowała, mając na przykład dwójkę dzieci, pojechać na Uniwersytet Łódzki, kiedy nie mam tam znajomych czy rodziny. A tylko dzięki nim mogę powiązać koniec z końcem, kiedy jeszcze nie mam pewności, że będę zarabiała poza uniwersytetem. Także dadza mi 2-2,5 tysiąca złotych, a ja mam do utrzymania rodzinę i nie mam przy sobie na przykład rodziców, którzy za darmo, nie będę musiała wydawać na opiekunkę, zajmą się moimi dziećmi [K9, 30-40, nauki społeczne].

Choć argument, który podaje respondentka, dotyczy pensji w Polsce, to został on przez nią użyty w dyskusji na temat mobilności w ogóle, w połączeniu z informacją o wyjeździe innego pracownika za granicę. Ani ta respondentka, ani większość osób w jej otoczeniu nie wyjeżdżało. Kwestia dzieci wiązała się tu z sytuacją finansową, która również miała znaczenie w decyzjach dotyczących mobilności. 


\subsection{Płaca i praca}

W decyzjach dotyczących mobilności akademickiej brano też pod uwagę kwestię pensji oraz organizacji pracy, a także inne aspekty ekonomiczne, np. kredyty:

Żeby wyjechać, to trzeba być nastawionym na naukę i tylko na naukę, a nie na zapewnianie sobie poczucia bezpieczeństwa. Bo ja mam niestety, ale ja mam coś przyczepione tutaj, a co nazywa się kredytem 3 tysiące złotych. Więc teraz jak najbardziej [K9, 30-40, nauki społeczne].

Ta rozmówczyni postrzegała mobilność jako szansę dla nauki, jednak sama dotąd nie wyjeżdżała. Chciała jednak zmienić tę sytuację i uważała, że był na to właśnie odpowiedni moment („teraz jak najbardziej”), ponieważ miała w końcu zapewnione poczucie bezpieczeństwa finansowego. To bezpieczeństwo wiele osób zapewniało sobie albo poprzez związek z osobą lepiej zarabiającą (kilka osób wskazało na to, choć dodało, że nie było to celem związku, a jedynie szczęśliwym trafem), albo poprzez pracę w innych miejscach niż uczelnia. Przykładowo, trudna była sytuacja mężczyzn utrzymujących rodzinę i chcących pracować na uczelni:

Ja uważam, że $w$ tej chwili mając czteroosobowa rodzinę, gdzie tylko ja pracuję, to minimum socjalne, to musiatoby być dla takiej rodziny okoto 5000 netto, a to mi bardzo dużo brakuje do tego, żeby nawet już nie mówiąc o jakichś wyjazdach zagranicznych, żeby zaspokajać. Bo ja mam też problemy zdrowotne $w$ rodzinie, więc zaspokojenie tego wszystkiego to $w$ granicach 50oo, ale ja nie osiagam takich dochodów. [...] nawet pracując dodatkowo to jest kłopot, żeby wiązać koniec z końcem. Gdybym byt singlem, to może bym sobie catkiem dobrze radzit, ale mając rodzinę na utrzymaniu, to duży klopot [M4, 40-50, humanistyka].

Z wywiadu nie wynika wprost, czy wpływało to na mobilność rozmówcy, można jednak wyobrazić sobie, że taki wpływ zależałby od tego, na ile zagraniczne pensje byłyby w stanie zapewnić rozmówcy i jego rodzinie utrzymanie w innym kraju, a także na ile dodatkowa praca podejmowana w Polsce (a wielu doktorów taką pracę podejmuje) nie utrudniałaby takiego wyjazdu. Wiadomo, że pensje za granicą były pokazywane przez wielu rozmówców jako dużo lepsze niż w Polsce (np. „to boli człowieka, to jednak boli, że nie jesteśmy tak doceniani, jak chociażby za granicą”), być może więc częściowo brano pod uwagę wyjazd w celu polepszenia swojej sytuacji. Znamienne jest jednak to, że nikt z naszych rozmówców nie poruszył tej kwestii, tzn. nie wspomniał o możliwości szukania pracy za granicą, aby zwiększyć swoje zarobki.

Obawy rozmówców o zostawienie pracy nie były jednak związane z pracami dodatkowymi, ale z pracą podstawową. Widać to np. w wypowiedzi dotyczącej mobilności krajowej: 
Zastanawiatam się kiedyś nad tym, czy jechać na wymianę między uczelniami w Polsce właśnie, no tam okres jest minimum dwóch lat [...]. Na coś takiego koleżanka pojechała, $w$ ramach jakieg os chyba nie programu, ale wymiany powiedzmy. I dowiedziałam się, na jakiej zasadzie to funkcjonuje i byłam $w$ dziale nauki i się okazało, że żeby jechać tam, chyba nawet na perspektywę pót roku czy do roku, wlaśnie na taka wymianę [...], to to nie jest na takiej zasadzie, jak Erasmus, że ja po prostu jadę sobie, tylko że składam wypowiedzenie i to mnie przeraziło. [...] Ja się po prostu bałam, że nie zostanę z powrotem po prostu przyjęta [K10, 30-40, humanistyka].

W wypowiedzi tej widać problem z organizacją wyjazdu - zamiast wziąć urlop bezpłatny, rozmówczyni musiałaby się zwolnić. W przypadku krótszych wyjazdów mogło też się okazać, że godziny dydaktyczne należało „odrobić”:

Staratam się o grant do Norwegii. I to byly takie stypendia, od tam iluś miesięcy do roku. Ja oczywiście strasznie chciałam pojechać na rok. [...] Natomiast moja szefowa wtedy powiedziata, że nie. Że nie mogę na rok, mogę na pót roku. Co bylo jakimś kompromisem. [...] I ja dostałam to stypendium, pojechałam na pót roku do Norwegii. Natomiast była straszna, może nie awantura, ale była kwestia tego, co z moimi zajęciami dydaktycznymi i co z moim pensum. I $w$ końcu zostato to tak zrobione. I szczerze mówiąc, nawet nie wiem, czy to jest zgodne z jakimiś przepisami, że ja zrobiłam przez jeden semestr całe pensum swoje. A przez te pót roku, które byłam $w$ Norwegii, bytam na urlopie bezplatnym. Czyli, de facto, np. pracowałam, przynajmniej, jeśli chodzi o dydaktykę, cały rok. Natomiast dostałam pensję tylko za pót roku $[\mathrm{K} 4,30-40$, nauki społeczne].

Nie dość więc, że pracodawca utrudnił naszej rozmówczyni wyjazd i skrócił go, to jeszcze zmuszona była ona do podwójnej pracy.

\subsection{Język}

Inną barierą w wyjazdach była słaba znajomość języka obcego, będąca też jedną z ważniejszych barier w mobilności badanych naukowców na terenie Unii Europejskiej (IDEA Consult 2010). Potrzeba biegłości językowej może być różna w zależności od reprezentowanej dyscypliny, kultury akademickiej kraju goszczącego (język badań, język spotkań, język dydaktyki) oraz samego języka, ponieważ np. nieznajomość niemieckiego w Niemczech sprawia większy kłopot niż nieznajomość fińskiego w Finlandii (Musselin 2004; Jöns 2009; Stephan, Franzoni i Scellato 2016). Jednak w przeprowadzonych przez nas wywiadach poruszano głównie kwestię znajomości języka angielskiego:

Akurat $w$ mojej dziedzinie ta mobilność jest nieunikniona. Jest nieunikniona ze względu na to, żeby chociażby poznać te wspótczesne trendy, które sq na różnych konferencjach, spotkaniach omawiane z zakresu ekonomii, z zakresu zarządzania. To jest nieuniknione, więc trzeba bylo w pewnym momencie jakby przekroczyć taka 
barierę, która jest językowa. Bo wszyscy z nas uczymy się języków, ale zawsze ta bariera istnieje. Więc nadal wiem, że ona w przypadku moim istnieje, dlatego że ja jestem jeszcze z pokolenia, kiedy uczono się języka rosyjskiego. Ja znam bardzo dobrze język rosyjski. [...] Więc miałam zawsze problem z językiem angielskim. No, ale niestety trzeba bylo się go pouczyć, no żeby właśnie być bardziej mobilnym. Powiedzmy obecnie jest on na poziomie, no lepiej niż podstawowym, ale można się porozumieć. I to jest chyba najważniejsze [K11, 30-40, nauki społeczne].

Chętnie bym na to pojechat, ale mam duży kompleks językowy. [...] No, mówmy o angielskim, na przyklad. To jest kompleks, z którego nie mogę się wyleczyć $i$ nie wiem, czy ja się kiedykolwiek wyleczę. A mianowicie, ja bym się chętnie $w$ takie rzeczy angażowat kiedyś, teraz znowu mam małe dziecko i bytby to problem, z wyjazdami, ze stażami. I wiele razy o tym myślałem, ale zawsze gdzieś wracatem do tego, no kurczę, ale ja nie znam języka, ja sobie nie poradzę itd. [...] Dogadać się dogadam, ale to nie jest tak, że jestem $w$ stanie swobodnie czytać, pisać po angielsku czy tam po niemiecku, to w ogóle nie znam tego języka, nie? [M5, 30-40, nauki społeczne].

Czy była to bariera możliwa do pokonania? Pierwsza wypowiedź sugeruje, że rozmówczyni uczyła się języka angielskiego („Bo wszyscy z nas uczymy się języków [...] obecnie jest on [angielski] na poziomie, no lepiej niż podstawowym, ale można się porozumieć"), ale zbyt wolno, żeby móc w najbliższym czasie porozumieć się w nim. W drugiej wypowiedzi rozmówca mówi o kompleksie, jednak nie wydaje się, żeby odczuwał potrzebę zmiany swojej sytuacji i nauczenia się języków. Problem języków dotyczył też filologów związanych z konkretnym językiem i mogącym go badać w konkretnych krajach. Mobilność była np. utrudniona u osób zajmujących się filologią polską:

W przypadku mojej dziedziny, czyli filologï polskiej, gdzie ma filolog polski pojechać na Erasmusa? Oczywiście sq polonistyki $w$ Czechach, z którymi mamy podpisane umowy, we Francji [...], ale na przykład językowa... Językowe przygotowanie polonistów, pracowników naukowych raczej nie sprzyja, żeby na te wyjazdy jeździć. Epizodycznie, po jednej osobie, oczywiście czasem trzeba wybłagać, kogoś namówić, żeby pojechał na Erasmusa, ktośjedzie, ale jeśli chodzi o Erasmusy, tojest minimalne $[\mathrm{K} 7,30-40$, humanistyka].

\section{Wnioski}

Jednym z najważniejszych wniosków wypływających z analiz zebranych w raporcie NOU jest to, że praca naukowa jest często traktowana przez współmałżonków i samych doktorów jako hobby, nieprzyczyniające się znacznie do utrzymania rodziny. Rozmówcy mogą sobie pozwolić na zajmowanie się tym hobby dlatego, że ich współmałżonek lepiej zarabia. Konsekwencje tego dla mobilności są duże - trudno 
jest bowiem „spakować” całą rodzinę i wyjechać - ten argument podawany był bardzo często.

Jednak wypowiedzi osób, które miały już za sobą doświadczenia mobilności, pokazują te same problemy, z którymi mimo wszystko potrafią sobie poradzić, gdyż są zdeterminowane do dalszych wyjazdów. Inne mają problem z wyobrażeniem sobie, jak można dane przeszkody pokonać, jak zorganizować sobie życie za granicą, a także brakuje im determinacji do wyjazdu, co - jak widzieliśmy - jest związane także z problemami z komunikacją w językach obcych. Charakterystyczną cechą wypowiedzi osób opisujących ograniczenia mobilności jest koncentracja na jednostce - na sobie („to mnie przeraziło”, „nie miałem ochoty”) lub innych („,chyba, że ktoś [...] przegra konkurs”). Nawet jeśli jest mowa o zbiorowościach w tym kontekście, to raczej o dyscyplinie niż o zespołach lub zakładach („W przypadku mojej dziedziny...”). Do tego mobilność związana jest nie tylko z ryzykiem, że nie będzie do czego wracać (np. z powodu utraty pracy), ale także z czasem potencjalnie trudnym finansowo.

Co zastanawiające, osoby mówiące o trudnościach z podjęciem decyzji o mobilności najwyraźniej miały na myśli długookresowe (nawet kilkuletnie) wyjazdy, podczas gdy osoby pokazujące zwyczajność tego typu doświadczeń mówiły na ogół o wyjazdach krótkich, nawet konferencyjnych.

\section{Przymus mobilności?}

Nasi rozmówcy widzieli często bariery związane z mobilnością i nie wyjeżdżali, mimo że wyjazd uważali za korzystny dla swojej pracy. Czy był więc sposób, żeby mimo wszystko wyjechali? Cytowany na samym początku rozmówca, pamiętający jeszcze czasy, gdy o wyjazd było trudno, powiedział, że nie planował dłuższego wyjazdu czy migracji: „Nie, nie. Musiałoby mnie życie zmusić, ale na razie nie”. Jak miałoby wyglądać takie zmuszenie przez życie? W jednej z proponowanych wersji reformy systemu nauki i edukacji wyższej sugerowano wymuszoną mobilność, a więc zmuszanie doktorów, by podejmowali pracę na innej uczelni niż macierzysta. Tego rodzaju propozycje nie zostały jednak wprowadzone, a mobilność, nawet krajowa, wciąż utrzymuje się na niskim poziomie, choć niektórzy spośród rozmówców upatrywali szansy na zwiększenie mobilności poprzez system konkursów:

Jeżeli chodzi o Polskę, to jest zupetnie zerowe, takie przemieszczanie się $w$ ramach Polski, chyba że ktoś, myślę, że to się będzie pojawialo, przegra konkurs, bo to się za chwilę zacznie robić, no zaczna się te sytuacje pojawiać tak, że stajemy do konkursu, kończy się nam umowa i to być może wymusi u osób, które nie sq rodzinnie jakoś mocno zakorzenione $w$ swoim miejscu pracy dotychczasowej jakąś mobilność $[\mathrm{K} 7$, 30-40, humanistyka]. 
Fragment ten jest o tyle interesujący, że rozmówczyni nie mówi o swoich doświadczeniach mobilności, lecz o większej społeczności, której jest częścią. Znamienne jest to, że za jedyny skuteczny sposób zwiększania mobilności akademickiej, uznaje ona jej wymuszenie. To wymuszanie pojawi się - co nie zostało jednoznacznie powiedziane - w momencie gdy ludzie po stracie pracy zaczną zgłaszać się do konkursów poza miejscem dotychczasowego zamieszkania lub by kontynuować swoją pracę (umowy o pracę dla adiunktów są coraz częściej zawierane na czas określony, po którym należy jeszcze raz przystąpić do konkursu na „swoje” miejsce pracy) i zaczną wzmacniać swoje CV.

Z przedstawionej analizy sytuacji rodzinnej i finansowej doktorów może wynikać, że wymuszanie mobilności prowadzi po prostu do odejścia od kariery naukowej tych, dla których rodzin pensja adiunkta nie jest pensją podstawową. Dobrze zarabiający małżonkowie raczej nie będą chętni do przeprowadzki. Taką przeprowadzkę utrudnia też posiadanie dzieci - dbałość o ich edukację, adaptację językową, ale też - jak wskazywała jedna z rozmówczyń - konieczność rezygnacji z darmowej opieki oferowanej przez babcie i dziadków, którzy zwykle są mniej mobilni. Wymuszanie mobilności na naukowcach mogłoby powodować poświęcanie kariery małżonków (a częściej żon niż mężów) lub rezygnację z „drogiego hobby” ich samych. Inną konsekwencją mogłaby być mobilność udawana, jak choćby w Islandii, gdzie zakaz pisania doktoratu na swojej uczelni spowodował fikcyjną mobilność, podczas której doktoranci dalej mieszkają i pracują w swoim kraju, ale przez Skype’a kontaktują się z zagranicznym promotorem. Z przeprowadzonych tam przez nas rozmów wynika, że czasami nawet obrona doktoratu odbywa się bez obecności autora, który nie jest na tyle mobilny, by dojechać na uczelnię, na której formalnie studiuje.

Co ciekawe, na tle cytowanych wcześniej badań mówiących o coraz większej konieczności mobilności w życiu i karierze naukowców w Europie i na świecie (Fahey i Kenway 2010a; 2010b; Kim 2010) w opowieściach badanych przez nas doktorów mobilność nie była konieczna, ani nawet wymagana. Pozostawała raczej szansą, dla niektórych niedostępną przygodą, która nie mogła ziścić się z powodów rodzinnych czy językowych. Z powyższych analiz można wysnuć wniosek, że mobilności można zacząć wymagać bardziej zdecydowanie od pracowników naukowych pod warunkiem, że będzie się to wiązało z adekwatnymi zmianami w zakresie ich pensji, tak by dochód doktorów miał dużo większy udział w utrzymaniu rodziny w porównaniu do dochodów małżonków zatrudnionych $\mathrm{np}$. w biznesie. Nawet wtedy jednak nie wiadomo, czy zaryzykowaliby oni utratę pracy przez małżonka, by np. wyjechać na staż. Dopiero bardziej skuteczne sposoby organizowania pracy dla małżonka oraz edukacji dla dzieci w kraju, do którego pracownicy naukowi mieliby migrować, a także rozwinięte doradztwo z tym związane mogłyby przynieść pozytywne skutki dla zwiększenia w polskim systemie nauki i szkolnictwa wyższego mobilności akademickiej. 


\section{Literatura}

Ackers, L. (2004). Managing relationships in peripatetic careers: Scientific mobility in the european union. Women's Studies International Forum. 27(3): 189-201.

Ackers, L., Balch, A., Scott, S., Currie, S., Millard, D. (2009). The Gender Dimension of Geographic Labour Mobility in the European Union. http://www.europarl.europa.eu/committees/fr/studiesdownload.html?languageDocument=EN\&file=28228 [30.09.2016].

Altbach, P.G., Knight, J. (2007). The Internationalization of Higher Education: Motivations and Realities. Journal of Studies in International Education. 11(3-4): 290-305.

Arai, K. (2010). Japanese science in a global world. Science. 328(5983): 1207.

Baruffaldi, S.H., Landoni, P. (2012). Return mobility and scientific productivity of researchers working abroad: The role of home country linkages. Research Policy. 41(9): 1655-1665.

Batorski, D., Bojanowski, M., Czerniawska, D. (2009). Diagnoza mobilności instytucjonalnej i geograficznej osób ze stopniem doktora w Polsce. http://www.nauka.gov.pl/ analizy-raporty-statystyki/diagnoza-mobilnosci-instytucjonalnej-i-geograficznej-osobze-stopniem-doktora-w-polsce-w-roku-2009, archiwum,1,akcja,pdf.html [30.09.2016].

Bauder, H. (2015). The international mobility of academics: A labour market perspective. International Migration. 53(1): 83-96.

Boring, P., Flanagan, K., Gagliardi, D., Kaloudis, A., Karakasidou, A. (2015). International mobility: Findings from a survey of researchers in the EU. Science and Public Policy. 1-16.

Cañibano, C., Bozeman, B. (2009). Curriculum vitae method in science policy and research evaluation: The state-of-the-art. Research Evaluation. 18(2): 86-94.

Corley, E.A., Sabharwal, M. (2007). Foreign-born academic scientists and engineers: Producing more and getting less than their U.S.-born peers? Research in Higher Education. 48(8): 909-940.

Czaika, M., Toma, S. (2015). Working Papers Path-dependency in International Academic Careers (No. 108). Oxford: International Migration Institute.

Dillon, N. (2001). Tackling the postdoc brain drain. European Molecular Biology Organization Reports. 2(9): 746-747. http://doi.org/10.1093/embo-reports/kve19o [30.09. 2016].

Fahey, J., Kenway, J. (2010a). International academic mobility: problematic and possible paradigms. Discourse: Studies in the Cultural Politics of Education. 31(5): 563-575.

Fahey, J., Kenway, J. (2010b). Moving ideas and mobile researchers: Australia in the global context. Australian Educational Researcher. 37(4): 103-114.

IDEA Consult (2010). Study on mobility patterns and career paths of EU researchers. FINAL Technical Report 3: Extra-EU mobility pilot study. http://cdigital.uv.mx/bitstream/123456789/33768/1/studyonmobility.pdf [30.09.2016].

Jarausch, K.H. (2005). Challenges of Internationalization: Careers in Humanities and Social Sciences. Arbeits- und Diskussionspapier. 3: 32-34.

Jöns, H. (2009). „Brain circulation” and transnational knowledge networks: Studying longterm effects of academic mobility to Germany, 1954-2000. Global Networks. 9(3): 315338. 
Kidd, J.M., Green, F. (2006). The careers of research scientists: Predictors of three dimensions of career commitment and intention to leave science. Personnel Review. 35(3): 229-251.

Kim, S. (2010). From Brain Drain to Brain Competition: Changing Opportunities and the Career Patterns of US-Trained Korean Academics. W: C.T. Clotfelter (red.). American Universities in a Global Market (335-369). Chicago: University of Chicago Press.

Kim, T. (2010). Transnational academic mobility, knowledge, and identity capital. Discourse: Studies in the Cultural Politics of Education. 31(5): 577-591.

Kowzan, P.,Zielińska, M., Kleina-Gwizdała, A., Prusinowska, M. (2016). „Niezostajemiczasu na pracę naukowq" Warunki pracy osób ze stopniem doktora, zatrudnionych na polskich uczelniach. Gdańsk - Bydgoszcz - Warszawa: Nowe Otwarcie Uniwersytetu. https://noweotwarcie.files.wordpress.com/2016/04/nie-zostaje-mi-czasu-napracc 499-naukowc485-raport-nou3.pdf [30.09.2016].

Kwiek, M., Antonowicz, D. (2015). The Changing Paths in Academic Careers in European Universities: Minor Steps and Major Milestones. W: T. Fumasoli, G. Goastellec, B.M. Kehm (red.). Academic Work and Careers in Europe: Trends, Challenges, Perspectives (41-68). Cham - Heidelberg - New York - Dordrecht - London: Springer.

Lehn, T. (2016). Academic Mobility: The Transnational Flow of U.S. Academic Staff to Higher Education Institutions in the Countries of the Gulf Cooperation Council. Minneapolis: University of Minnesota.

McNair, S. (2009). Migration, Communities and Lifelong Learning. IFLL Thematic Paper 3. Leicester: National Institute of Adult Continuing Education.

Morano-Foadi, S. (2005). Scientific mobility, career progression, and excellence in the European Research Area. International Migration. 43(5): 133-162.

Musselin, C. (2004). Towards a European Academic Labour Market ? Some Lessons Drawn from Empirical Studies on Academic Mobility Towards a European academic labour market? Some lessons drawn from empirical studies on academic mobility. Higher Education. 48(1): 55-78.

Paradeise, C., Thoenig, J.-C. (2013). Academic Institutions in Search of Quality: local orders and global standards. Organization Studies. 34(2): 189-218.

Stephan, P., Franzoni, C., Scellato, G. (2016). Global competition for scientific talent: Evidence from location decisions of PhDs and postdocs in 16 countries. Industrial and Corporate Change. 25(3): 457-485.

Vohlídalová, M. (2014). Academic mobility in the context of linked lives. Human Affairs. 24(1): 89-102.

Wagner, I. (2011). Becoming Transnational Professional. Kariery i mobilność polskich elit naukowych. Warszawa: Scholar.

Zielińska, M. (2016). Autoreferat rozprawy doktorskiej pt. „Miejsce, mobilność i edukacja. Dorośli Polacy w Reykjaviku". https://www.academia.edu/24197664/Autoreferat_ rozprawy_doktorskiej_pt._Miejsce_mobilno\%C5\%9B\%C4\%87_i_edukacja._Doro\%C5\%9Bli_Polacy_w_Reykjaviku [30.09.2016].

Zielińska, M., Kowzan, P., Ragnarsdóttir, H. (2014). Polish complementary schools in Iceland and England. Intercultural Education. 25(5): 405-417. 


\section{International mobility of Polish PhD holders - obstacles and possibilities}

ABSTRACT. The paper presents results of qualitative research on $\mathrm{PhD}$ holders working at Polish universities, regarding their international mobility. The respondents' opinions on mobility, their experiences of it (e.g. experiences of study visits), as well as obstacles, which prevented mobility were taken into consideration and analysed. Special attention was given to family issues (related to partners and children), language competences and working conditions. Declarations regarding mobility were compared to data on the respondents' sources of income. For some of them the partner's income was a primary means of livelihood. Therefore, we argue that demanding more mobility from the researchers may be counter-productive, since the mobility of the family could put the partner's income at risk.

KEYWORDS: academic mobility, gender, PhDs, migration

CYTOWANIE: Zielińska, M., Kowzan, P. (2016). Mobilność zagraniczna polskich doktorów - możliwości i bariery. Nauka i Szkolnictwo Wyższe. 1(47): 181-201. DOI: 10.14746/nisw.2016.1.7. 